\title{
A Perspective on CHN-US Trade Relations Based on the Perspective of the New Crown Epidemic
}

\author{
Chengshuang Lv ${ }^{1, ~ *}$, Caihui Wang1, Jiaojiao Xu1 \\ ${ }^{1}$ College of Economics \& Management, Tianjin University of Science and Technology, Tianjin, 300457, China \\ * Corresponding author: Chengshuang Lv (Chelsealv@mail.tust.edu.cn)
}

\begin{abstract}
The Covid-19 pneumonia epidemic has broken out and spread in more than 215 countries, with more than 7 million confirmed cases worldwide, which will definitely have a huge negative impact on the global economy, and it has also given birth to populism and trade protectionism in some countries such as the United States. In particular, the trade friction between China and the United States has not been completely resolved, and the direction of the trade relationship has become an important issue in the post-epidemic era. Using retrospective research methods, dynamic analysis methods, and path analysis methods, we discovered the uncertainties in Sino-US trade relations under the epidemic. In the post-epidemic era, Sino-US trade relations will show long-term trade disputes, accompanied by complex politicization and normalization of talks while fighting. However, SinoUS trade is highly interdependent and cannot be divided. Therefore, China upholds to jointly build a community with a shared future for mankind, comprehensively deepens reform and opening up, adheres to dialogue and consultation, stabilizes the ballast of economic and trade relations, crosses the "Thucydides trap", and implements the strategy of expanding domestic demand to take the lead in restoring the economy during the epidemic. Responding to the trade war provoked by the United States against China also provides reference for in-depth research on trade-related theories.
\end{abstract}

Keywords: COVID-19, CHN-US trade relations, CHN-US trade war, Towards, Community of human destiny.

\section{Introduction}

In March 2020, the World Health Organization (WHO) officially announced that the new coronavirus epidemic (2019-COVID) has entered a global pandemic. As of June 8, 2020 , the number of confirmed cases in the United States has exceeded 1.94 million, and the number of confirmed cases outside of China has exceeded 6.9 million cases [1]. This has brought about a huge negative impact on both the Chinese and American economies. It has also spawned the United States' renownism and trade protectionism. As the two major economies with the largest trade volume in the world, they signed the agreement in December 2019. In the first phase of the trade agreement, trade frictions have temporarily eased but have not been completely resolved. China is the first to control the epidemic in the global economy, and must seize the advantage of taking the lead in recovering the economy to deal with the Sino-US trade dispute. Predicting the trend of Sino-US trade relations in the post-epidemic era, and proposing several new ideas for effectively responding to Sino-US trade frictions from the perspective of the new crown epidemic will help China and the United States to abandon the positioning of strategic competitors and the "Cold War mentality" and return to dialogue and negotiation The economic logic of cooperation with trade.

\section{The Uncertainty of Sino-US Trade Relations under the New Crown Epidemic}

\subsection{Advantages of Intelligent Supervision of Food Safety in Beijing, Tianjin and Fujian}

The first phase of the China-US economic and trade agreement reached in January 2020 will temporarily ease the 17-month Sino-US trade war, but it does not mean that the
Sino-US trade dispute will be completely resolved. The 2020 "Chinese Economist" questionnaire survey results show that most economists judge that the Sino-US trade friction will be difficult to disappear in the next five years, and even $40 \%$ of economists believe that economic and trade friction will worsen. Especially at the beginning of 2020, a sudden public health incident, the new crown pneumonia virus, has spread globally. The epidemic has blocked international logistics channels, sharply reduced import and export demand, increased risk of capital chain rupture, and restricted export delivery capabilities of US companies. It is more difficult to implement the first phase of the economic and trade agreement. The US government will not cancel the tariffs that have been imposed, and the tariffs that have been cancelled may be imposed again. On March 23, 2020, the Trump administration imposed tariffs on medical products exported from China, resulting in a shortage of key medical equipment and rising costs in the United States. In April 2020, the U.S. Department of Commerce announced that it would impose new export restrictions on China, Russia and other countries on the grounds of endangering U.S. security to prevent other countries from acquiring U.S. weapons and military technology into military use through civilian and commercial means. Security poses a threat. On May 15, 2020, the U.S. Department of Commerce announced plans to restrict Huawei from using U.S. technology and software to design and manufacture semiconductors outside the U.S. This time limit is limited to the geographical scope and involves industrial chain links compared to the restriction that Huawei was included in the entity list in 2019. The strictness has been significantly improved, the pertinence is stronger, and the risk of impacting the global supply chain is greater. Under the new crown epidemic, these measures have increased the instability and uncertainty of Sino-US trade relations [2].

All in all, many issues in Sino-US trade relations under the new crown epidemic are still unresolved, which has created a 
survival crisis for Chinese technology and trade enterprises. As of April 2020, the year-on-year growth rate of China-US imports and exports has continued to decline, from February to April. The decline was $20.9 \%, 20.1 \%$, and $15.2 \%$, respectively. In April, the epidemic in China was under control, and the resumption of work and production proceeded in an orderly manner, and the decline has slowed down. In terms of cumulative trade volume, the import and export volume hit a double low in February 2020. The cumulative export volume was 42.972 billion U.S. dollars, the cumulative import volume was 17.6 billion U.S. dollars, and the trade surplus was as low as 25,372 billion U.S. dollars. Under control, the total volume of imports and exports in April was more than twice that of February, reaching 137.06 billion U.S. dollars, and the trade surplus also rose to 63.676 billion U.S. dollars (see Table 1). The new crown epidemic will continue for a long time in the world. The prevention and control of the epidemic will become normal. The uncertainty of Sino-US trade relations will remain. An analysis of the historical evolution and future development of Sino-US trade relations will help China better. Responding to trade pressure from the United States.

Table 1. Sino-U.S. bilateral trade statistics

\begin{tabular}{|c|c|c|c|c|c|}
\hline Year-month & Export value & Import value & $\begin{array}{c}\text { Total import and } \\
\text { export }\end{array}$ & $\begin{array}{c}\text { Year growth rate of total } \\
\text { import and export\% }\end{array}$ & difference \\
\hline $2020-02$ & 429.72 & 176.00 & 605.72 & -20.90 & 253.72 \\
\hline $2020-03$ & 682.55 & 274.75 & 957.30 & -20.10 & 407.80 \\
\hline $2020-04$ & 1003.68 & 366.92 & 1370.60 & -15.20 & 636.76 \\
\hline
\end{tabular}

\section{The Trend of Sino-US Trade Relations in the Post-epidemic Era}

After the outbreak of the global new crown epidemic, SinoUS trade relations have accelerated. The success of China's domestic epidemic prevention has protected one-fifth of the world's population. China also assists other countries and actively participates in the World Health Organization's epidemic prevention work. As of April 12, China's National Agency for International Cooperation and Development data shows that China has provided anti-epidemic assistance to 139 countries and 4 international organizations in five batches. After the domestic epidemic has been effectively controlled, the resumption of work and production proceeded in an orderly manner. In the 2020 government work report, it is mentioned that efforts should be focused on the "six stability" and "six guarantees". The "six guarantees" are the focus of this year's "six stability" work [3]. Maintaining the bottom line of the "six guarantees" is to stabilize the economic fundamentals; to ensure stability and seek progress in stability, under the correct guidance of the Party Central Committee, the economic defense war in the post-epidemic era will also succeed. In contrast, the performance of the U.S. epidemic prevention has disappointed the American people and the international community. As of 16:00 on June 8, 2020, Beijing time, the latest WHO data shows that the United States has confirmed more than 1.94 million cases and more than 110,000 deaths. In the international community, at the White House press conference on the morning of May 29, Trump announced that the United States would terminate its relationship with the World Health Organization and terminate its submission to the World Health Organization because the World Health Organization "refuses to implement the reforms requested by the United States." Pay the dues. In this context, the United States continues to provoke a trade war against China and "should dump the pot" to China. It can be seen that the future of Sino-US trade relations will be longterm in terms of time, tasks will be arduous, and accompanied by political issues. The complexity and the normalization of talks while fighting will be an unavoidable historical inevitability and challenge. However, China's trade has been deeply embedded in the global value chain, and Sino-US trade is still interdependent and inseparable, and win-win cooperation is the mainstream [4].

\section{Several New Ideas for Dealing with Sino-US Trade Frictions}

\subsection{Building A Community of Human Destiny, Across the "Thucydides Trap"}

In 2015, when Xi Jinping visited the United States, he said: "There is no' Thucydides trap' in the world, but repeated strategic misjudgments among major powers may cause themselves a 'Thucydides trap' situation.". The "Thucydides Trap" is not a realistic objective existence, but is caused by the United States' subjective misjudgment of positioning China as a strategic competitor. China and other countries do not have the objective conditions to fall into the "Thucydides trap", but it does not mean that China and the United States can ignore the construction of relations between major powers. The relationship between major powers is always the dialectical unity of cooperation and game. To achieve winwin cooperation between China and the United States, it is necessary for both parties to work together, constructively manage and analyze, and transform conflict points into points of cooperation. The new crown epidemic continues to spread globally, and the post-epidemic era will have a profound and huge impact on global economic and social development [5]. On June 7, 2020, China released the "China Action to Fight the New Coronary Pneumonia Epidemic" white paper: "Together to build a human health community, unity and cooperation is the most powerful weapon for the international community to defeat the epidemic." However, due to differences in political systems, cultural traditions, etc., the United States has improperly controlled the epidemic, and accused China of withdrawing from the World Health Organization and raising tariffs on China. These performances are undoubtedly unpopular in the global crisis of fighting the epidemic. In the face of global public health risks, it is necessary to overcome the separation of the interests of different societies, nations, and nations from the fate of the entire mankind, grasp the consistency among them, and insist on building a community with a shared future for mankind [6]. 


\subsection{Deepen Reform and Expand Opening to the Outside World}

China-U.S. trade relations are highly interdependent. China insists on deepening comprehensive reforms, opening wider to the outside world, continuing to conduct extensive and farreaching trade exchanges with the U.S., increasing imports from the U.S., and taking the initiative to reduce China's trade surplus. Balancing trade and not deliberately pursuing excessive surpluses in order to alleviate China's external pressure [7]. Give the pilot free trade zone greater reform autonomy, accelerate the construction of free trade ports such as Hainan, and add pilot free trade zones in the central and western regions; further reduce the number of negative lists, expand foreign imports, and create an open, internationally recognized business Environment: Make full use of the Eurasian Continental Bridge, actively and steadily promote the "Belt and Road", promote new models of international cooperation, participate in the international industrial division to a greater extent, and expand China's influence. During this epidemic, the cooperation between China and ASEAN on the "Belt and Road" initiative played a positive role in restoring economic development. On May 24, 2020, the National Development and Reform Commission stated that the total GDP of the Beijing-Tianjin-Hebei, Guangdong-Hong KongMacao Greater Bay Area, and the Yangtze River Delta totaled 43.6 trillion yuan, accounting for $44 \%$ of the country's total GDP. Therefore, the creation of a world-class city cluster in the Beijing-Tianjin-Hebei region, the Yangtze River Delta Economic Belt and the Guangdong-Hong Kong-Macao Greater Bay Area have become important engines for China's economy in the post-epidemic era.

\subsection{Dialogue and Consultation to Stabilize Economic and Trade Relations Ballast Stone}

Today, as the global value chain is deeply embedded, China and the United States, as the two largest economies in the world, should uphold peaceful dialogue and consultation to resolve trade disputes. Fighting a trade war will harm the common interests of the two countries and abandon the "Cold War mentality" and " "Zero-sum game" is the ballast stone that stabilizes good trade relations. From the historical evolution of Sino-US trade relations, it can be seen that since the establishment of diplomatic relations between China and the United States, ballast stones have always played a role in maintaining Sino-US relations. From 1971 to 1991, the United States used China to resist the Soviet Union. Therefore, CHN-US relations were the most important at the time. Ballast stone is the existence of the Soviet Union [8]. Although the total trade volume between China and the United States continues to rise, China is not of strategic importance to the United States. After the disintegration of the Soviet Union in 1991, to 2016, China's economy has grown rapidly over the past two decades. In 2001, China joined the WTO and Sino-US trade entered a golden period. During this period, the most important ballast in the relations between the two countries was the Chinese economy. With rapid growth, the total trade volume between China and the United States has risen rapidly year after year. The United States has seized the opportunity of China's rapid development and the demographic dividend has benefited greatly from it. Currently, the United States defines China as a strategic competitor relationship under the "Thucydides Trap". At this time, the trade relationship between China and the United States is a common most basic ballast stone, and disputes are resolved through dialogue at this level. Negotiate to resolve differences, return to the WTO framework as soon as possible to resolve disputes, and better promote global free trade and fair trade. The door to China's peaceful consultation and dialogue will always be open, and we will seek a mutually beneficial economic and trade development path, build a new type of CHN-US relationship between major powers, and speed up the resolution of complex political issues in CHN-US trade [9]11.

\subsection{Implement A Strategy to Expand Domestic Demand and Boost the Domestic Economy}

The global epidemic is spreading and the economic and trade situation is severe. In the short term, Sino-US trade volume has dropped sharply. In the long-term, Sino-US trade relations depend on the global competitive landscape and strategic game between the two sides. The International Monetary Fund (IMF) predicts that the global economy will decline by $3 \%$ in 2020 and the economies of developed countries will decline by $6 \%$. The impact of the new crown epidemic will be greater than the 2008 financial crisis. China's epidemic has taken the lead in the world to be effectively controlled. The resumption of work and production, and the resumption of business and markets proceeded in an orderly manner. However, GDP fell by $6.8 \%$ in the first quarter, the lowest quarterly growth rate since the reform and opening up in 1978. It can be seen that domestic supply and demand are at the same time. Was severely hit by the epidemic. Therefore, it is not only necessary to carry out supply-side structural reforms, but also to implement strategies to expand domestic demand to restore confidence in consumption and investment affected by the epidemic, so as to avoid insufficient demand and lead to insufficient supply, forcing the domestic economy to enter a spiral downward spiral of supply-demand. Cycle [10]. On the one hand, through proactive fiscal policies to increase the deficit rate, issue special treasury bonds to fight the epidemic, increase local government special bonds, and appropriately increase public consumption, etc., actively play the role of fiscal funds to provide direct and strong support for expanding domestic demand and stabilizing growth; The prudent monetary policy maintains reasonable and sufficient liquidity through measures such as RRR cuts, interest rate cuts, and refinancing, and guides the loan market to lower interest rates to provide more financial support for the real economy. On the other hand, actively expand effective investment, increase R\&D intensity and human capital investment, and increase labor productivity. The first is the general insufficient investment in basic research, the basic research and applied basic research capabilities of enterprises, and the overall increase in the research and development intensity of new foundations such as $5 \mathrm{G}$ and data centers to increase labor productivity; the second is to give priority to the R\&D plus deduction policy in major innovation areas, Procurement of advanced production equipment, key parts, key materials, localized value-added tax deduction policies and other important measures; the third is to comprehensively accelerate the promotion of a talent training system at all levels that matches the construction of an innovative country, and establish a "retraining system." Carry out large-scale vocational education and training to achieve labor upgrade and transformation matching; fourth, take advantage of the opportunity of the "return" of scientific 
and technological talents after the epidemic, and actively formulate targeted policies to attract overseas scientific and technological talents (especially domestic scientific and technological talents and overseas students) to return to China. At the same time, we should give play to the basic role of consumption in expanding domestic demand, stimulate consumption of 1.4 billion residents, improve the consumption environment, enhance the quality of consumption, and avoid costs such as rent and taxes to raise commodity prices. In the post-epidemic era, it is necessary to make good use of policies to stimulate domestic demand to seek China's first economic advantage in the world's major economies, and to respond to the trade and technology wars initiated by the United States to contain China's rise.

\section{Acknowledgment}

This work was financially supported by The Philosophy and Social Science Planning Project of the Propaganda Department of Tianjin Municipal Party Committee (TJYJ20010).

\section{References}

[1] Guobing Shen (2020). Impact of the global spread of COVID19 on international trade and mitigation measures. People's Forum · Academic Frontiers,no.07,p.1-6.

[2] Shixiong Ni (2019).70 Years of China-us Relations: Theory and Practice. International observers,no.05,p.1-25.
[3] Xinquan $\mathrm{Tu}$ (2017).U.S. Trade policy toward China since China's accession to WTO. World Economic Studies,no.11,p.30-36.

[4] Yonghong $\mathrm{Du}$ (2019).The nature of sino-US trade frictions and China's countermeasures. China's circulation economy,vol.33,no.09,p.42-53.

[5] Liang Ren (2017).Trump's Trade Policy and the US section 301 Investigation against China. International trade issues,no.12,p.153-165.

[6] Buckley P J, Verbeke A(2016).Smiling and crying curves in international business. International Business Review,vol.25,no.3,p.749-752.

[7] Shih C, Huang C(2020).Competing for a Better Role Relation: International Relations, Sino-US Rivalry and Game of Weiqi.Journal of Chinese Political Science,vol.25,no.1,p.1-19.

[8] Bin Liu,Yuanpeng Ming,Weiguang Chen(2019).Trade frictions between established and rising Powers: A comparative analysis based on trade frictions between China and the United States and Between Japan and the United States. The international trade,no.12,p.12-18.

[9] Jiyong Chen (2018). Background, Causes, Essence and Countermeasures of Sino-US Trade War. Journal of Wuhan University (Philosophy and Social Sciences),vol.71,no.05,p.72-81.

[10] Xiaotian Li (2019). Sino-US trade conflicts from the perspective of economic interdependence: causes, enlightenment and prospects. Studies of International Relations,no.05,p.109-135. 